\section{REPORTS OF THE AUSTRALIAN ANTARCTIC EXPEDITION.}

$T$ HE scientific results of the Australian Antarctic Expedition are being published with commendable promptitude. Of the five parts recently received the most generally interesting is the report on the Brachiopoda by Dr. J. Allan Thomson, Wellington, N.Z. The Brachiopods recorded, though not many in number, are relatively rich in species, a new genus, Amphithyris (family Terebratellidæ), and new species of seven other genera being described. The author gives a summary of the known distribution of Brachiopods in South Temperate and Antarctic seas, and discusses the bearing of the facts on the theories of southern land connections, "which it is one of the aims of Antarctic expeditions to prove or disprove." He points out that the known larvæ of Brachiopods, with the exception of those of Lingula and Discina (sensu lato), have no mouth during the free-swimming stage, and that they soon settle down. Consequently, the deep oceans are barriers which Brachiopods, the majority of which live on the submarine slopes of continents and adjacent islands, and their larvæ cannot cross, and therefore cases of discontinuous distribution of these shallow-water forms have an important significance.

Dr. Thomson considers there is abundant evidence, from the associated molluscan fauna, that the Patagonian (Miocene) of South America and the Oamaruian (older Tertiary) of New Zealand had a much warmer climate than the present, and that the occurrence of the same Brachiopod genera and species in the Oligocene-Miocene of the Antarctic strongly suggests that at this period the Antarctic seas were also warmer. Mr. Tate Regan, in his report on the Terra Nova fishes, inclined to the view that the coasts of Antarctica were washed by cold seas probably throughout the Tertiary period, but in Dr. Thomson's view the geological evidence all points the other way.

From a consideration of the distribution of the Brachiopods he arrives at the following conclusions: Connections-not necessarily land-bridges, but chains of islands or shallow submarine ridges-must have existed between Australia and South Africa at some date prior to the Tertiary, by which the primitive genera of the Terebratellidæ attained their present distribution in South Africa, St. Paul's and Marion Islands, Australia, and New Zealand. The specific and generic distinctness of the recent New Zealand and Australian forms precludes any land connections between these areas in Pliocene or later times. The two groups of Terebratellidæ concerned would seem to have originated on the coasts of Gondwana Land, on the remnants of which they now survive; the Kerguelen area apparently did not share in the connection with Gondwana Land. Connections between Australia, New Zealand, the Macquarie Islands, Kerguelen, Antarctica, and South America must have occurred in the early Tertiary, but New Zealand was not connected at the same time with Australia and Antarctica. The connections between New Zealand, Antarctica, and South America may have existed from an earlier period. It does not appear probable that Australia was connected directly with Kerguelen and Antarctica during the Cretaceous or early Tertiary. The southern connections were broken, much as at present, by Miocene times, and since that period there have been no renewed connections between the southern continents and island areas except, possibly, between South America, Antarctica, and the adjacent islands.

Dr. W. G. Ridewood records (vol. iii., part 2), from off Adelie Land and Queen Mary Land, four species of Cephalodiscus-hodgsoni, nigrescens, solidus, and densus-and gives details of the external features of the colonies and notes on the colour and structure of the zooids. For further details of these species reference may be made to Dr. Ridewood's recent report on the specimens of Cephalodiscus collected by the British Antarctic (Terra Nova) Expedition, a notice of which will appear in another issue of NATURE.

A brief account of the Euphausiacea and Mysidacea is given by Dr. W. M. Tattersall (vol. v., part 5), and of the Cumacea and Phyllocarida by Dr. W. T. Calman (part 6).

Prof. A. Dendy (vol. vi., part I) reports on the calcareous sponges. The Antarctic forms comprise two new species of Leucetta, a new species of Leucandra, and a new variety of Grantia. In the account of the monaxon spicules of a variety of Leucosolenia botryoides from Macquarie Island, Prof. Dendy takes the opportunity of correcting an error in the late Prof. Minchin's well-known memoir on the British species of this genus. Minchin considered that the monaxons of Leucosolenia were separable into two kinds, one very refringent, the other much less so, the refringent monaxons being fewer, straighter, more slender, and having the distal barb less distinct or absent. Prof. Dendy points out that the explanation of these differences is simply that some of the monaxons were viewed as they lay on edge, while others were seen lying flat.

\section{NEW PROCEDURE AT AMERICAN MAGNETIC OBSERVATORIES.}

$\mathrm{I}$ accordance with the usual practice of the United States Coast and Geodetic Survey, two years, ${ }^{19}{ }^{1} 5$ and 19I6, are dealt with in the Results of Observations at the magnetic observatories at Sitka and Honolulu, which have recently been published. In previous years the curves were read unsmoothed exactly at the hour local mean time. Commencing with $19 \mathrm{I} 5$, the hourly value represents the mean ordinate for sixty minutes ending with the hour of the $135^{\text {th }}$ meridian at Sitka ( $135^{\circ} 20 \cdot x^{\prime}$ W.), and of the $165^{\text {th }}$ meridian at Honolulu ( $\left.\mathrm{I}_{5} 8^{\circ}{ }_{3} \cdot \mathcal{S}^{\prime} \mathrm{W}.\right)$. The value entered, for instance, under $2 \mathrm{~h}$. really belongs to $1 \cdot 5 \mathrm{~h}$. Diurnal inequalities continue to be given, as in the past, only for Ioq (quiet) days a month chosen locally, and for the $5 \mathrm{q}$ (international quiet) days, but hourly means are given for all days. The adoption of mean ordinates instead of instantaneous readings is in accordance with what is now probably the usual practice. Unless it is followed, all-day diurnal inequalities for disturbed months are apt to be very ragged. But the adoption of means for sixty minutes ending at the hour, instead of sixty minutes centring at the hour, is a practice not generally followed except in Germany. Even if the procedure had distinct advantages over the ordinary one, its spasmodic adoption by individual observatories or in individual countries has the serious drawback of introducing diversity where uniformity is desirable. This is especially true of the international quiet days, the special object of which is to supply exactly corresponding data from different observatories.

The advantage claimed for the new procedure is that it makes the day self-contained, whereas with the ordinary procedure the values for the first and last midnights depend, one on the last half-hour of the previous day, the other on the first half-hour of the following day. This argument has much weight in the case of elements like rainfall or duration of sunshine, where we deal with aggregates. But in the case of magnetism the procedure does not really make

NO. 2577 , VOL. IO3] 
the day self-contained unless we neglect the n.c. (noncyclic) changes, which are seldom really negligible. These changes should, in any case, be explicitly shown, as they are generally in part of instrumental origin. The only reference to them at Honolulu seems to be a statement that they have been allowed for in the case of the 5q-day inequalities. At Sitka there is the further statement that, so far as possible, days with large n.c. changes have not been chosen for the roq days. It would be interesting to know how the n.c. corrections were found for the $5 q$ days, and whether they were entirely omitted for the Ioq days.

An idea of the size of the n.c. changes on quiet days can usually be derived from the size of the difference between the mean daily values for these days and for all days. From the twenty-four monthly means of $19^{1} 5$ and I9r6 given for all days and for the roq days, we find for the mean algebraic excess of the latter class over the former $+6 \cdot 0 \gamma$ in $H$ (horizontal force) and $+5.4 \gamma$ in $\mathrm{V}$ (vertical force) at Sitka, and $+7.5 \gamma$ in $\mathrm{H}$ and $-\mathrm{I} \cdot \mathrm{I} \gamma$ in $\mathrm{V}$ at Honolulu. In $\mathrm{D}$ (declination) the mean difference between the two sets of mean values is only about $0.05^{\prime}$ at both stations. The $5 q$ days give very nearly the same mean daily values as the roq days. We should naturally infer that while the n.c. change may be negligible in $D$, it is probably by no means negligible in $\mathrm{H}$ at either station, or in $V$ at Sitka. Confirmatory evidence is derivable from the highly disturbed days, the characteristics of which are usually the direct opposite of those of quiet days. If we take as representing disturbance the five days of largest daily range in each month, we find that on the average the monthly mean values derived from these days fall short of the corresponding all-day means by $14.4 \gamma$ in $H$ and $15.3 \gamma$ in V at Sitka, and by $9.1 \gamma$ in $\mathrm{H}$ and $2.3 \gamma$ in $\mathrm{V}$ at Honolulu. Disturbance in $\mathrm{V}$ is unusually large at Sitka, and exceptionally small at Honolulu, which, presumably, explains the large difference between the mean values from the $5 \mathrm{q}$ and $5 \mathrm{~d}$ days at the former station, and the small difference at the latter station. If a diurnal inequality were to be derived from the $5 \mathrm{~d}$ days, as has recently been suggested, the n.c. element would almost certainly be of great importance at Sitka in $\mathrm{H}$ and $\mathrm{V}$.

Another feature wanting explanation is that the $5 q$ days are shown in the tables as days of $165^{\circ} \mathrm{W}$. at Honolulu, and as days of $135^{\circ} \mathrm{W}$. at Sitka, whereas they are really 24-hour periods commencing at Greenwich midnight. It is to be hoped that this is only camouflage, just as when values belonging really to $\mathrm{I} \cdot 5 \mathrm{~h}$. are entered under the heading $2 \mathrm{~h}$., because considerable disturbance is occasionally experienced within less than nine hours of the end of true international quiet days. Explanation on this point, on the n.c. changes, and on the effect on the ranges of the diurnal inequalities consequent on the change of procedure would be welcome in the next issue of these valuable publications.

$$
\text { C. Chree. }
$$

\section{FOREST RESEARCH IN EUROPE.}

$A$ USEFUL account of forest research in Europe by $\mathrm{Mr}$. S. Howard has appeared in the Indian Forester for September last. "Forest research, in many instances, necessitates observations over long periods of time, longer than an individual man's working vears, and over widely separated areas. Some institution is necessary, therefore, to direct methods for the sake of uniformity, and to continue ideas, despite the necessary changes in the research personnel." Germany was the first country to organise research, this movement dating from I868, when it was proposed at a meeting of prominent foresters at Regensburg that the larger States, Austria, Prussia, and Bavaria, should have independent research institutes. It was finally decided in 1870 that forest research should be properly organised, and that the research institutes in all the States were to be combined with the educational branch-that is to say, the president of the forest college was also to be president of the research institute. In 1912 all German States of importance had their forestry institutes (in each case combined with the college of forestry) united under the German Forest Research Association, which meets, as a rule, twice a year. The Prussian Research Institute, united with the Forestry College at Eberswalde, has six branches, dealing with sylviculture, physical chemistry, meteorology, plant physiology, zoology, and mycology.

Besides the headquarters at Eberswalde, there are numerous experimental plots of trees all over Prussia. These were at first put under the local forest officer, but this proved a failure; and for more than twenty years all work connected with the plots has been done by the research staff at Eberswalde. The sylvicultural branch compiles yield tables and statistics, and has carried out investigations on exotic trees, rootformation, manures, technical properties of wood, seed tests, etc. It is to be noted that the tests of strengths of wood and the like are done by technical experts at Charlottenburg, and not by the Forest Research Institute. The meteorology branch is especially concerned with experiments on the influence of forests on climate. The plant physiology branch is purely botanical, and takes up subjects like the formation of annual rings, the influence of locality on seeds, the influence of soil factors on trees, etc. The zoology branch is concerned with zoological researches, so far as they concern forests, and with control methods; the physical chemistry branch with the chemistry of soils, the formation of humus, the formation of pan, etc.; and the mycology branch with mycology in its relation to forestry and control methods.

Forest research was organised in France in $\mathbf{1 8 8 2}$, but was hopelessly carried out. Experiments were begun, but were usually badly organised and badly performed, and ceased absolutely between 1896 and 1902. The research work proposed in France was to cost i2ool. per annum. Germany has actually been spending 6oool., Switzerland zoool., and Sweden, roughly, 880 l. a year.

Mr. Howard gives also an account of the International Forest Research Association, which met at Mariabrunn in 1893 and 1903 , at Brunswick in 1896 , at Zurich in rgoo, and at Brussels in I9Io. Most European countries are members, but France is not, or, if she is, has taken no active part. The usefulness of these international meetings was undoubted. For example, it was soon found essential to have some classification of thinnings, if results were to be comparable. The Prussian classification was adopted in rgo3.

\section{THE CONSERVATION OF OUR CEREAL RESERVES. ${ }^{1}$}

$T H E$ dangers to which grain stored under ordinary conditions is exposed may be classified under four heads:-(I) The attacks of rats and mice, (2) those of insects and mites, (3) those of moulds and bacteria, and (4) the process known as "heating." The amount of damage due to rats and mice is, no doubt, enormous; but might be avoided by any rational system of storage, and is a matter

1 Abstract of a lecture delivered at King's College, London, on March 12, under the auspices of the Imperial Studies Committee of the University London, by Prof. Arthur Dendy, F.R.S. 